\title{
PENGEMBANGAN KARIER GURU DI MADRASAH IBTIDAIYAH (MI) AL- IFADAH PENJARINGAN JAKARTA UTARA
}

\begin{abstract}
As'ad $^{*}$
Abstract: The objective of this research was to understand comprehensively the development of teachers' career at the Al-Ifadah Islamic secondary school it was a qualitative research with study case method conducted in Penjaringan, north Jakarta.Qualitative method was used with case studying approach. Head master and teachers as data source. In this research data collecting with triangulation technique to get credibility in this research grouped as (1) give longer time in research location (2) observation 60 documentation. After with the data categorized and coding were done in two data summary appropriately with the research problem and sub problems then and data analysis about completeness and relevance data examined.The finding lead to the recommendation teacher's for continues them studies to get more education to apply teachers' training in term of develop teacher's career. Socialization leading and socialization training in order to get the Al-Ifadah Islamic secondary school running well, it is recommended for education head masters and teachers to improve accountability in assessing standard of Islamic secondary school.
\end{abstract}

Keyword: career development, education, and training.

\section{PENDAHULUAN}

Sekolah merupakan lembaga pendidikan yang dirancang untuk mencerdaskan kehidupan anak bangsa. Di sana diselenggarakan pembelajaran dengan segenap kelengkapan perangkatnya seperti, bangunan gedung, peralatan, kegiatan terjadwal, seperangkat aturan, dan sebagainya dengan tujuan menghasilkan manusia yang cerdas, mandiri, kompetitif, dan dapat berkontribusi terhadap pembangunan bangsa.

Dalam mewujudkan cita-cita di atas, di samping sarana dan prasarana yang memadai, pendanaan yang cukup, adanya kerjasama antara sekolah dengan masyarakat, pemerintah daerah dan pemerintah pusat, faktor lain yang tidak kalah penting dalam mewujudkan cita-cita pendidikan adalah adanya guru yang kompeten, terampil, inovatif, berdedikasi tinggi, dan memiliki loyalitas terhadap lembaga pendidikan di mana mereka mengajar.

Berbagai upaya sudah dilakukan oleh pemerintah dalam meningkatkan kompetensi guru di antaranya, memperhatikan pengembangan karier guru dengan melalui penyelenggarakan pelatihan berkala, mendorong dan memberikan kesempatan kepada guru untuk melanjutkan pendidikan ke jenjang yang lebih tinggi, pemberian beasiswa, tunjangan, distribusi buku, pengadaan lab dan alat pembelajaran, peningkatan sarana dan prasarana sekolah, dan lain sebagainya.

Madrasah Ibtidaiyah (MI) Al-Ifadah yang berlokasi di kelurahan dan kecamatan Penjaringan Jakarta Utara merupakan sekolah formal sederajat dengan sekolah dasar (SD) yang memadukan materi agama dangan materi pengetahuan umum. Madrasah yang berdiri sejak tahun 1995 di tengah-tengah pemukiman padat penduduk dengan tata kelola lingkungan yang kurang baik merupakan harapan masyarakat setempat dalam memberikan pendidikan baik pengetahuan agama maupun 
pengetahuan umum kepada anak-akanya. Banyak keterbatasan dan kekurangan yang ada di madrasah tersebut di antaranya: 1) faktor eksternal sekolah, a) lokasi dan gedung madrasah menyatu dengan pemukiman rumah padat penduduk dengan tata kelola lingkungan yang tidak baik. Hal tersebut tentu berdampak pada ketidak kondusifan proses pembelajaran, b) sekolah menjadi langganan banjir di setiap musim hujan ( kurang lebih dua minggu aktifitas pembelajaran diliburkan), c) kurang lebih $40 \mathrm{~m}$ dari sekolah tersebut terdapat lokalisasi atau hiburan malam yang cukup banyak (panjang lokalisasi $\pm 300 \mathrm{~m}$ ), 2) kondisi internal sekolah, a) luas area sekolah yang sangat terbatas sehingga tidak ada halaman dan taman sekolah, area parkir, dan kegiatan apel rutin atau upacara dilaksanakan dijalan utama warga, b) gedung bangunan yang kurang memadai sehingga kapasitas siswa/siswi tidak berimbang dengan luas ruangan kelas, c) keterbatasan gedung, sekolah terpaksa membuat perpustakaan tambahan di bawah fly over tol pintu tol Gedong Panjang. Hal tersebut tentu sangat membahayakan keselamatan siswa/siswi. Dengan keterbatasan yang ada dan permasalahan yang kompleks, MI Al-Ifadah banyak meraih prestasi yang cukup membanggakan di antarnya: 1) Madrasah Ibtidaiyah (MI) Al-Ifadah peringkat 10 besar dari 64 sekolah setingkatnya di wilayah Jakarta Utara, 2) Juara II lomba cerdas cermat antar Madrasah se wilayah Jakarta Utara, 3) Juara II lomba Sains Matematika dan Ilmu Pengetahuan Alam tingkat kecamatan Penjaringan (dari 19 sekolah), dan lain sebagainya. Di samping prestasi yang cukup membanggakan, hal unik lain yang peneliti temukan adalah pengembangan karier guru di madrasah tersebut berjalan sangat baik. Hal tersebut dapat dilihat meskipun status Madrasah Ibtidaiyah (MI) Al-Ifadah adalah sekolah swasta, hampir 30\% guru pegawai negeri sipil (PNS) lahir dan ditugaskan di sekolah tersebut. Walaupun Madrsah Ibtidaiyah (MI) Al-Ifadah adalah sekolah kecil dan banyak keterbatasan baik keuangan, fasilitas, sarana dan prasarana, namun MI Al-Ifadah sangat peduli terhadap peningkatan pendidikan guru. Hal tersebut dapat dilihat bahwa sejak berdirinya MI Al-Ifadah 90\% guru-gurunya belum sarjana strata satu (S1), kebanyakan mereka adalah tamatan diploma dan Madrasah Aliyah (MA). Saat ini, seluruh guru MI Al-Ifadah sudah menyelesaikan sarjana strata satu dan bahkan ada tujuh guru telah melanjutkan pendidikan tinggi program strata dua (S2) di perguruan tinggi negeri (PTN) maupun perguruan tinggi swasta (PTS) yang ada di wilayah Jakarta dan sekitarnya. Begitu juga perhatian terhadap program pelatihan di Madrasah Ibtidaiyah (MI) Al-Ifadah cukup tinggi, meskipun kondisi keuangan dan fasilitas sangat terbatas. Pelatihan baik di internal maupun eksternal sekolah yang sudah diprogramkan bersama berjalan cukup baik dan diyakini efektif dalam menjadikan guru lebih terampil, disiplin, dan produktif. Kedua strategi di atas baik pendidikan dan pelatihan merupakan langkah awal dalam merencanakan pengembangan karier guru di masa yang akan datang.

\section{Pengembangan Karier}

Menurut Lloyd L. Byars dan Leslie W. Rue (2008:194), “career development is an angoing, formalized effort by an organization that focuses on developing and enriching the organization's human resources in light of both the employees' and the organization's needs". Pengembangan karier adalah upaya yang terus menerus, usaha formal organisasi yang fokus pada pengembangan, dan penyediaan sumber daya manusia di organisasi baik bagi kebutuhan pegawai maupun kebutuhan organisasi. Menurut Robert N Luissier (2008:129), "career development is the process of gaining skill, experience, and education to 
achieve career objectives". Pengembangan karier adalah proses mendapatkan keterampilan, pengalaman, dan pendidikan untuk mencapai tujuan karier. Menurut Danang Sunyoto (2012:184), pengembangan karier pegawai dapat dilakukan melalui dua cara yaitu: 1) cara diklat, contoh: a) melanjutkan studi atau pendidikan pegawai baik di dalam negeri maupun diluar negeri, b) memberikan pelatihan baik di dalam organisasi maupun di luar organisasi, c) memberikan pelatihan sambil bekerja (on the jon traning), 2) cara non diklat, contoh: a) memberikan penghargaan kepada pegawai, b) memberi sanksi pegawai, c) mempromosikan pegawai ke jabatan yang lebih tinggi, d) merotasi pegawai ke jabatan lain yang setara dengan jabatan semula.

\section{Pendidikan formal}

Dalam pendidikan sebagaimana yang diatur dalam undang-undang bahwa jalur pendidikan terbagi menjadi dua yaitu: 1) pendidikan formal, dan 2) pendidikan non formal. Berikut ini akan dijelaskan jalur pendidikan formal sesuai dengan pokok pembahasan di atas.

Menurut Undang-undang Sistem Pendidikan Nasional Nomor 19 Tahun 2005 Pasal 1 Ayat 2 bahwa, "pendidikan formal adalah jalur pendidikan terstruktur dan berjenjang yang terdiri atas pendidikan dasar, pendidikan menengah, dan pendidikan tinggi". Dikatakan jalur pendidikan formal karena proses pendidikan tersebut diselenggarakan di sekolah secara berjenjang dan berkesinambungan. Sebagai konsekuensinya yang berhak masuk ke jalur pendidikan formal hanyalah mereka yang dalam batas-batas umur masa belajar dan studi. Dalam undang-undang Nomor 20 Tahun 2003 tentang Sistem Pendidikan Nasional Pasal 1 ayat 8 disebutkan bahwa “jenjang pendidikan adalah tahapan pendidikan yang ditetapkan berdasarkan tingkat perkembangan peserta didik, tujuan yang akan dicapai, dan kemampuan yang akan dikembangkan". Dalam pendidikan, jenjang pendidikan formal terdiri atas tiga jejang sebagai berikut: 1) pendidikan dasar merupakan jenjang pendidikan yang melandasi jenjang pendidikan menengah. Pendidikan dasar berbentuk Sekolah Dasar (SD) dan Madrasah Ibtidaiyah (MI) atau bentuk lain yang sederajat, serta Sekolah Menengah Pertama yang disebuat dengan (SMP), dan Madrasah Tsanawiyah (MTs) atau bentuk lain yang sederajat, 2) pendidikan menengah merupakan lanjutan dari pendidikan dasar (SD/MI dan SMP/MTs) yang terdiri atas pendidikan menengah umum dan pendidikan menengah kejuruan. Pendidikan menengah berbentuk Sekolah Menengah Atas (SMA), Madrasah Aliyah (MA), Sekolah Menengah Kejuruan (SMK), dan Madrasah Aliyah Kejuruan (MAK) atau bentuk lain yang sederajat, 3) pendidikan tinggi adalah jenjang pendidikan setelah pendidikan menengah (SMA/SMK dan MA/MAK) yang mencakup program diploma, program sarjana, program magister, program doktor, program profesi, dan program spesialis, yang diselenggarakan oleh perguruan tinggi berdasarkan kebudayaan bangsa indonesia. Pendidikan tinggi merupakan kelanjutan pendidikan menengah. Dalam undang-undang diatur bahwa jenjang pendidikan tinggi merupakan sarat mutlak bagi tenaga pendidik maupun kependidikan. Hal tersebut bertujuan agar dapat meningkatkan mutu dan kualitas pendidikan. Dalam Peraturan Pemerintah (PP) Nomor 19 Tahun 2005 bab IV pasal 28 dikatakan bahwa: 1) pendidik harus memiliki kualifikasi akademik dan kompetensi sebagai agen pembelajaran, sehat jasmani dan ruhani, serta memiliki kemampuan untuk mewujudkan tujuan pendidikan nasional, 2) kualifikasi akademik sebagaimana 
dimaksud oleh ayat 1 adalah tingkat pendidikan minimal yang harus dipenuhi oleh seorang pendidik yang dibuktikan dengan ijazah dan atau sertifikat keahlian yang relevan sesuai dengan ketentuan perundang-udangan yang berlaku.

\section{Pelatihan}

Menurut George T. Milkovich dan John W. Boudreau (1997:408), "training is a systematic process to foster the acquisition of skills, rules, concepts, or ettiudes that result in an improved macth between employee characteristics an employment requirements". Pelatihan adalah proses yang sistematis untuk membantu meningkatkan kemampuan, disiplin, konsep, dan sikap yang menghasilkan sebuah pengembangan yang sesuai dengan aturan kepribadian pekerja dan tuntutan pekerja. Robert L. Mathis dan John $\mathrm{H}$. Jackson (2011:250), "training is the process whereby people acquire capabilities to perform jobs". Pelatihan adalah proses yang mana seseorang memperoleh kemampuan untuk melakukan atau menyelesaikan tugas-tugasnya dengan baik. Menurut Lloyd L. Byars dan Leslie W. Rue (2008:10), "training is learning process that involves the acquisition of knowledge, skill and abilities (KAS) necessary to successfully perform a job". Pelatihan adalah pembelajaran yang melibatkan kemampuan-kemampuan untuk mendapatkan pengetahuan, keterampilan, dan kemampuan diri dengan tujuan mensukseskan pelaksanaan suatu pekerjaan.

Terkait dengan pelaksanaan, pelatihan dapat diselenggarakan di internal maupun di ekstenal organisasi. pelatihan yang diselanggarakan di internal organisasi tentu membutuhkan biaya yang cukup besar dibandingkan pelatihan yang dilaksanakan di eksternal organisasi. tetapi jika ditinjau dari segi manfaatnya tentu pelatihan internal organasisi lebih besar.

\section{METODOLOGI PENELITIAN}

Penelitian ini dilaksanakan di Madrasah Ibtidaiyah Al-Ifadah kelurahan dan Penjaringan Jakarta Utara dengan pertimbangan bahwa status sekolah tersebut adalah swasta, uniknya pengembangan karier guru di sana cukup efektif seperti, 30\% guru PNS lahir dan dibaktikan di sekolah tersebut, dan 30\% guru-guru melanjutkan pendidikan pasca sarjana di PTN maupun PTS di wilayah Jakarta dan sekitarnya. Yang unik lainnya adalah meskipun kondisi keuangan dan fasilitas sangat terbatas, perhatian sekolah terhadap pelatihan baik di internal maupun eksternal sekolah yang sudah diprogramkan bersama berjalan cukup baik meskipun cost biaya pelatihan sangat besar. Adapun Penelitian ini menggunakan pendekatan kualitatif dan metode yang digunakan dalam penelitian adalah metode studi kasus.

\section{TEMUAN PENELITIAN DAN PEMBAHASAN}

\section{Pendidikan}

Banyak faktor yang mempengaruhi kualitas pendidikan di antaranya, sarana dan prasarana yang memadai, pendanaan yang cukup, dukungan dari pemerimtah pusat, daerah, dan masyarakat, serta adanya guru yang profesional dan kompeten. Berabagai upaya telah dilakukan oleh kepala Madrasah Ibtidaiyah Al-Ifadah dalam meningkatkan 
mutu sekolah, di antaranya meningkatkan pendidikan guru. Mengingat guru mempunyai peran, fungsi, dan kedudukan yang sangat strategis dalam mewujudkan cita-cita pendidikan sehingga perlu dikembangkan kompetensinya, salah satunya melalui jalur pendidikan. Temuan tersebut sesuai dengan Peraturan Pemerintah RI Nomor 19 Tahun 2005 tentang Standar Nasional Pendidikan yang meliputi: standar isi, standar kompetensi kelulusan, standar proses, standar tenaga pendidik dan kependidikan, standar sarana dan prasarana, standar pengelolaan pendidikan, standar pembiayaan pendidikan, dan standar penilaian pendidikan.

Di samping peningkatan pendidikan guru dapat berpengaruh terhadap output pendidikan, jenjang pendidikan formal merupakan salah satu langkah dalam pengembangan karier seseorang. Hal ini sesuai dengan pendapat Robert N Luissier (2008: 129), "career development is the process of gaining skill, experience, and education to achieve career objectives". Pengembangan karier adalah proses mendapatkan keterampilan, pengalaman, dan pendidikan untuk mencapai tujuan karier.Kepala sekolah selalu menenkankan kepada guru akan pentingnya pendidikan. Hal tersebut dapat dilihat sejak berdirinya Madrasah Ibtidaiyah Al-Ifadah, hampir 90\% guru-guru belum sarjana strata satu (S1). Melalui program kerjasama dengan pendidikan tinggi, kepala sekolah berhasil mendorong guru-guru dalam menyelesaikan pendidikan strata satu (S1). Hal tersebut diyakini kepala sekolah bahwa dengan modal pendidikan tinggi, sekolah tersebut dapat mengorbitkan sebagian guru-guru menjadi pegawai negeri sipil (PNS) dan yang lainnya sudah mendapatkan sertifikasi. Atas dasar inilah kepala sekolah memberikan kesempatan dan bantuan kepada guru-guru untuk melanjutkan pendidikan program strata dua (S2). Sekarang ini, di Madrasah Ibtidaiyah Al-Ifadah ada delapan guru yang sedang melanjutkan program strata dua (S2) baik di PTN maupun PTS di wilayah Jakarta dan sekitarnya. Dengan adanya guru-guru yang melanjutkan ke jenjang pendidikan tinggi, ini adalah langkah awal dalam pengembangan karier guru ke dapan. Kepala sekolah dapat mempromosikan guru-guru tersebut ke jabatan yang lebih tinggi dari sebelumnya, seperti menjadi kepala sekolah, kenaikan golongan, pengawas atau supervisor, praktisi pendidikan, dosen dan lain sebagainya.

Temuan tersebut sesuai dengan teori yang dikemukakan oleh Danang Sunyoto (2012:184), pengembangan karier pegawai dapat dilakukan melalui dua cara sebagai berikut: 1) cara diklat, seperti: a) melanjutkan studi atau pendidikan pegawai baik di dalam negeri maupun diluar negeri, b) memberikan pelatihan baik di dalam organisasi maupun di luar organisasi, c) memberikan pelatihan sambil bekerja (on the jon traning), 2) cara non diklat, contoh: a) memberikan penghargaan kepada pegawai, b) memberi sanksi pegawai, c) mempromosikan pegawai ke jabatan yang lebih tinggi, d) merotasi pegawai ke jabatan lain yang setara dengan jabatan semula. 


\section{Pelatihan}

Dalam workshop atau rapat kerja sekolah yang dilaksanakan sebelum tahun ajaran baru, pelatihan merupakan salah satu agenda pembahasan yang pendapatkan perhatian. Ada dua mekanisme dalam pelaksanaan program pelatihan di Madrasah Ibtidaiyah Al-Ifadah, 1) pelatihan internal sekolah yaitu, pelatihan yang diselenggarakan di sekolah dengan sasaran materi lebih pada meningkatkan kompetensi guru dalam pembelajaran seperti, pembuatan silabus dan rencana program pembelajaran (RPP). Sebagai trainernya adalah pengawas, kepala sekolah, guru senior, dan guru-guru yang kualifeid, atau pihak sekolah mengundang trainer dari lembaga lain seperti, pengawas pendidikan dari kantor wilayah Departemen Agama Jakarta Utara, dosen, praktisi pendidikan, dan konsultan pendidikan. Adapun pesertanya adalah seluruh pendidik dan tenaga kependidikan, 2) pelatihan eksternal sekolah yaitu, pelatihan yang diselenggarakan di luar sekolah. Dengan mekanisme kepala sekolah mendelegasikan guru untuk ikut serta dalam pelatihan sesuai dengan kebutuhan sekolah dan biaya sepenuhnya ditanggung oleh pihak sekolah. Temuan tersebut sesuai dengan teori yang dikemukakan oleh Goetsch dan Davis (2010:262), "training can be provided in-house: through corporate-owned education and training facilitaties; in conjuction with colleges, universities, and pofessional organizations; or via satellite downlinks." Sebuah organisasi dapat memberikan pelatihan secara internal atau dikenal dengan in-house training. In house training dapat dilakukan di tempat sendiri dengan bekerja sama dengan universitas, lembaga profesional yang menyediakan jasa pendidikan dan pelatihan atau dapat melalui pembelajaran jarak jauh. Robert L. Mathis dan John H. Jackson (2011:250), menjelaskan "training is the process whereby people acquire capabilities to perform jobs". Pelatihan adalah proses yang mana seseorang memperoleh kemampuan untuk melakukan atau menyelesaikan tugas-tugasnya dengan baik. Menurut Lloyd L. Byars dan Leslie W. Rue (2008:10), "training is learning process that involves the acquisition of knowledge, skill and abilities (KAS) necessary to successfully perform a job". Pelatihan adalah pembelajaran yang melibatkan kemampuan-kemampuan untuk mendapatkan pengetahuan, keterampilan, dan kemampuan diri dengan tujuan mensukseskan pelaksanaan suatu pekerjaan. Selain pelatihan dapat meningkatkan kompetensi guru, pelatihan juga merupakan salah satu upaya dalam pengembangan karier guru. Hal itulah yang membuat kepala Madrasah Ibtidaiyah Al-Ifadah menjadikan pelatihan sebagai program unggulan di sekolah tersebut. Dengan pelatihan yang berkala, pengetahuan, keterampilan, kedisiplinan, dan motivasi guru semakin tinggi, hal tersebut berdampak pada pengembangan dirinya maupun karier kedepannya.Temuan ini sesuai dengan teori yang dikemukakan oleh William B. Werther dan Jr Keith Davis (1993:391), "career development is the principal aim of such programs has been to help employees analyze their abilities and interests to better match personal needs of the organization. In addition, career development is a critical tool through which management can increase productivity, improve employee attitudes toward work and develop greater worker satisfaction". Pengembangan karier adalah tujuan utama dari program-program yang telah membantu pegawai menganalisa kemampuan, dan keinginan untuk menselaraskan dengan kepentingan pribadi organisasi. Selain itu, pengembangan karier adalah alat penting di mana manajemen dapat meningkatkan produktivitas, meningkatkan sikap pegawai terhadap pekerjaan, dan dapat menumbuhkan kepuasan pegawai.

Pendapat yang sama juga dikemukakan oleh Malayu S.P Hasibuan (2008:72-73) bahwa pengembangan karier secara formal adalah pegawai yang ditugaskan oleh organisasinya untuk mengikuti pendidikan dan latihan, baik yang dilakukan di internal 
organisasi maupun yang dilaksanakan oleh lembaga-lembaga pendidikan atau latihan. Hal yang senada juga dikemukakan Danang Sunyoto (2012:184), pengembangan karier pegawai dapat dilakukan melalui dua cara yaitu: 1) cara diklat, contoh: a) melanjutkan studi atau pendidikan pegawai baik di dalam negeri maupun diluar negeri, b) memberikan pelatihan baik di dalam organisasi maupun di luar organisasi, c) memberikan pelatihan sambil bekerja (on the jon traning), 2) cara non diklat, contoh: a) memberikan penghargaan kepada pegawai, b) memberi sanksi pegawai, c) mempromosikan pegawai ke jabatan yang lebih tinggi, d) merotasi pegawai ke jabatan lain yang setara dengan jabatan semula. Luissier (2008:129) menjelaskan, "career development is the process of gaining skill, experience, and education to achieve career objectives". Pengembangan karier adalah proses mendapatkan keterampilan, pengalaman, dan pendidikan untuk mencapai tujuan karier. Menurut Danang Sunyoto (2012:184), pengembangan karier pegawai dapat dilakukan melalui dua cara yaitu: 1) cara diklat, contoh: a) melanjutkan studi atau pendidikan pegawai baik di dalam negeri maupun diluar negeri, b) memberikan pelatihan baik di dalam organisasi maupun di luar organisasi, c) memberikan pelatihan sambil bekerja (on the jon traning), 2) cara non diklat, contoh: a) memberikan penghargaan kepada pegawai, b) memberi sanksi pegawai, c) mempromosikan pegawai ke jabatan yang lebih tinggi, d) merotasi pegawai ke jabatan lain yang setara dengan jabatan semula.

Kesimpulan: Berdasarkan hasil temuan dan pembahasan temuan penelitian yang dikemukakan di atas dapat disimpulkan bahwa: (1) Pengembangan karier guru melalui peningkatan pendidikan guru di MI Al-Ifadah sangat diperhatikan oleh kepala sekolah. Hal tersebut dapat dilihat adanya kerja sama antara pihak sekolah dengan perguruan tinggi swasta (PTS) dalam penyelesaian program strata satu (S1). (2) Kepala sekolah juga memberikan kesempatan dan dukungan bagi guru-guru untuk melanjutkan pendidikan tinggi program strata dua (S2) baik di PTN maupun PTS. Selain peningkatan pendidikan guru sebagai upaya pengembangan karier guru, langkah lain dalam pengembangan karier di MI Al-Ifadah adalah melalui program pelatihan yang berkala. Pelatihan merupakan salah satu agenda penting dalam work shop atau rapat kerja sekolah yang dilaksanakan sebelum tahun ajaran baru.

Rekomendasi: Sejalan dengan temuan dan simpulan penelitian, maka rekomendasi ini disampaikan kepada kepala sekolah, guru dan tenaga kependidikan Madrasah Ibtidaiyah Al-Ifadah Penjaringan Jakarta Utara sebagai berikut: (1) Peningkatan pendidikan guru, kepala sekolah hendaknya memprogramkan hal tersebut, sehingga jenjang pendidikan tinggi tidak didominasi oleh guru-guru PNS saja, namun guruguru honorer pun mendapatkan peluang yang sama sehingga tidak terjadi kesenjangan pendidikan antar guru. (2) Pelatihan yang diprogramkan di MI Al-Ifadah memainkan peran penting dalam meningkatkan kompetensi guru dan pengembangan karier guru yang berpengaruh terhadap pembelajaran dan prestasi sekolah. Untuk itu, kuantitas pelatihan perlu ditingkatkan lagi.

\section{DAFTAR RUJUKAN}

Anthony, William P., Perrewe, Pamela L., dan Kamar, K Mihele. Human Resoure Management.Boston : MGraw-Hill/Irwin, 2008. 
ArdosoGomes, Faustino. Manajemen Sumber Daya Manusia. Yogyakarta: Andi Offset, 2003.

Astetter, William B. The Personnel Funtion in Eduational Administration. New York : Mamillan Publishing Company, 1981.

Byars, LIoyd L., dan Rue, Leslie W., Human Resoure Management, Ninth Edition. Boston : MGraw-Hill/Irwin, 2008.

Fuad, Noor dan Ahmad, Gofur. Integrated Human Resoures Development Berdasarkan Pendekatan B-HRM, BT dan PD. Jakarta: Grasindo, 2009.

Hasibuan, Malayu S.P. Manajemen Sumber Daya Manusia, Edisi Revisi. Jakarta: Bumi Aksara, 2011.

Kadarisman, M. Manajemen Pengembangan Sumber Daya Manusia. (Depok: Rajagrafindo Persaja, 2012.

Mathis, Robert L. dan Jakson, John H. Human Resoure Management. Australia: SouthWestern engage Learning, 2011.

Noe, Raymond A., Hollenbek, John R., Gerhart, Barry., Wright, Patrik M. Human Resoure Management. Boston : MGraw-Hill Higher Eduation, 2003.

Peraturan Pemerintah Republik Indonesia Nomor 19 Tahun 2005 tentang Standar Nasional Pendidikan.

Peraturan Menteri Pendidikan dan Kebudayaan Republik Indonesia Nomor 70 Tahun 2013 tentang Kerangka Dasar dan Struktur Kurikulum Sekolah Menengah Kejuruan dan Madrasah Aliyah Kejuruan.

Pidarta, Made. Landasan Pendidikan, Stimulus Ilmu Pendidikan Bercorak Indonesia. Jakarta: Reneka Cipta, 2007.

Rowley, Chris dan Jackson, Keith.Human Resources Management: The Key Conceps, penerjemah Elviyola Pawan. Jakarta: Rajagrafindo Persada, 2012.

Suwatno, dan Juni Priansa, Donni.Manajemen SDM dalam Organisai Publik dan Bisnis. Bandung: Alfabeta, 2011.

Suyoto, Danang. Manajemen Sumber Daya Manusia Dilengkapi dengan Budaya Organisasi, Pengembangan Organisasi dan Outsouring. Yogyakarta: enter for Aademi Publishing Servie, 2012. 
Undang-Undang Nomor 20 Tahun 2003 tentang Sistem Pendidikan Nasional.

Werther, William B, dan Jr. Keith Davis. Human Resources Management.USA: McGrawHills, 1993. 